\title{
Operational Risk Assessment in 3PL for Maritime Transportation
}

\author{
J.C. Osorio ${ }^{1}$, D.F. Manotas ${ }^{1}$, J.L. García ${ }^{2}$ \\ ${ }^{1}$ Escuela de Ingeniería Industrial, Universidad del Valle, Cali, \\ Colombia \\ 2 Departamento de Ingeniería Industrial y Manufactura, \\ Universidad Autónoma de Ciudad Juárez, \\ Mexico \\ \{juan.osorio,diego.manotas\}@ correounivalle.edu.co, jorge.garcia@uacj.mx
}

\begin{abstract}
Supply chain risk management is an important activity in current supply chain management. Operational risk is one of the most important risks in supply chains. The operational risk assessment process includes risk identification and evaluation and prioritization. On the other hand, the participation of Third Party Logistics providers (3PL) in supply chains has been increasing, and it is important to consider how their presence affects risk management. Maritime transportation is a fundamental activity in global supply chain and it is essential for the commercial trade. We propose a multicriteria approach for risk assessment in a 3PL company for maritime transportation. The multicriteria model uses Fuzzy QFD for risk evaluation and prioritization. The approach is applied in an international company with a branch office located in Colombia.
\end{abstract}

Keywords: supply chain risk management, operational risk, multicriteria, fuzzy QFD, maritime transportation.

\section{Introduction}

Maritime transportation is one of the most important industries with its immense share in the global trade. Maritime transportation is a cost-effective method which enables companies to transfer an international cargo between two seaports [1].

The increasing need of the companies to focus on the core business object has generated a trend oriented to outsource different activities. In this context, supply chain activities have evolved from a first stage where we have companies that are responsible for their logistics processes up to the current trend with companies who have delegated all their logistics activities to specialized agents [2].

According with this, maritime companies are important 3PL organizations and have a direct influence in the strategic results of the supply chains therefore managing risk in these companies is an important activity for the supply chain risk management. 
In recent years, fuzzy QFD has become a widely used quality tool developed to satisfy customer need in product design and development. Fuzzy QFD provides a mean of translating customer requirements into appropriate technical requirement for each stage of product development and production [3] but in recent years its scope has been expanded towards multicriteria decision making.

The basis of QFD is to obtain and translate customer needs into engineering characteristics, and subsequently into part characteristics, process plans and production requirements [1].

Although there are many papers related with QFD and FQFD applications in maritime transportation $([4][5][6][1][7][8][9])$, none of them applied FQFD to operational risk assessment.

Besides, there are some papers related to QFD applications in risk management such as [10] and [11] still there is a gap in risk assessment research and Fuzzy QFD.

QFD approach to enhance maritime supply chain resilience taking both customer requirements and maritime risks into consideration is presented in [4] however still is necessary to include risk prioritization which is the aim of this research. Table 1 shows the scope of some papers related to QFD and FQFD applications in supply chain, 3PL and 4PL, risk and maritime transportation.

Table 1. Papers related to QFD and FQFD applications.

\begin{tabular}{ll}
\hline \multicolumn{1}{c}{ Applications } & \multicolumn{1}{c}{ Papers } \\
\hline QFD and risk management & {$[11][10]$} \\
FQFD in supply chain management & {$[12][13][14][15][16][17]$} \\
FQFD in 3PL (4PL) applications & {$[18][19]$} \\
QFD in maritime transportation & {$[5][6][1]$} \\
FQFD in maritime transportation & {$[7][8][9]$} \\
QFD in maritime transportation and risk & {$[4]$} \\
\hline
\end{tabular}

We proposed a novel approach to risk assessment using FQFD to prioritize the risk according to the strategical objectives of the company. The approach is presented in the next section and we show an application in a real case in Colombia.

\section{Methodological Approach}

We proposed a FQFD methodology. This proposal is based in [12] and Fig. 1 shows its development. Previous to phase 1 , it is necessary to define the team (experts of the company that are directly involved in the decision process).

The first phase is to stablish the internal variables "WHATs" and then defining the relative importance according to the linguistic scale presented in Table 2. This scale can change if the company or the experts like to use another; the important is that the scale involves linguistic variables and their correspondent fuzzy numbers.

Once the internal variables are defined the team must identify the strategic objectives (HOWs) related to the process where the risks are considering. 
To determine the weight of the "HOWs" in the phase 4 the team must stablish the "WHAT" - "HOW" correlation scores using the scale in Table 2.

Finally, the experts determining the risks impact on the strategical objectives and obtain the risk priority. According to this priority, the company can stablish the mitigation or elimination plans to improve the operational risk management process.

Table 2. Linguistic scale to FQFD.

\begin{tabular}{lc}
\hline Linguistic variable & Fuzzy number \\
\hline Very Low (VL) & $(0,1,2)$ \\
Low $(\mathrm{L})$ & $(2,3,4)$ \\
Medium $(\mathrm{M})$ & $(4,5,6)$ \\
High $(\mathrm{H})$ & $(6,7,8)$ \\
Very High $(\mathrm{VH})$ & $(8,9,10)$ \\
\hline
\end{tabular}

Phase 1

Identifying the internal variables "WHAT"

Phase 2

Determining the relative importance of the "WHATs"

Phase 3

Identifying the strategic objectives or "HOW"

Phase 4

Determining the "WHAT" - "HOW" correlation scores

Phase 5

Determining the weight of the "HOWs"

Phase 6

Determining risk impact on the strategic objectives ("HOWs")

Phase 7

Prioritizing risks

Fig. 1. Methodological approach to risk prioritization.

\section{Case of Study}

The methodological approach was used in a maritime company with filial in Colombia. This company is one of the largest and the most recognized in global container shipping. 
The company operates 480 offices in 150 countries. It owns 480 ships and operates 200 routs in the world.

The team was composed by the operations manager (OM), commercial manager $(\mathrm{CM})$, export manager (EM) and branch manager (BM). According to the methodological approach the first phase was to define the internal variables "WHATs" and their weights in triangular fuzzy numbers (TNF) (Table 3).

Table 2. WHATs and their weights.

\begin{tabular}{lccccccc}
\hline \multicolumn{1}{c}{ WHATs } & OM & CM & EM & BM & \multicolumn{2}{c}{$\begin{array}{c}\text { Ponderations } \\
\text { (TFN) }\end{array}$} \\
\hline Good resource utilization - GRU & H & VH & VH & H & 7 & 8 & 9 \\
Good customer service - GCS & VH & H & H & H & 7 & 8 & 9 \\
Economic benefits - EB & VH & VH & VH & VH & 8 & 9 & 10 \\
Company positioning -CP & H & M & H & M & 5 & 6 & 7 \\
Market participation increasing - MPI & M & H & H & VH & 6 & 7 & 8 \\
\hline
\end{tabular}

The next phase was to identifying strategical objectives (HOWs), in this case they were: Improve market share position, Optimize profit per shipment, Ensure market coverage, Optimize space ships and Customer loyalty

Then the team determines the "WHAT" - "HOW" correlation scores. In Fig. 2 these correlations are presented. For example the team opinions about the impact of improve market share position with the good resource utilization is high for the operations manager, commercial manager and export manager, but is medium for the branch manager

\begin{tabular}{|c|c|c|c|c|c|c|c|c|c|c|c|c|c|c|c|c|c|c|c|c|}
\hline \multirow{3}{*}{ WHATs } & \multicolumn{20}{|c|}{ Strategic objectives (HOWs) } \\
\hline & \multicolumn{4}{|c|}{$\begin{array}{l}\text { Improve market share } \\
\text { position }\end{array}$} & \multicolumn{4}{|c|}{$\begin{array}{l}\text { Optimize profit per } \\
\text { shipment }\end{array}$} & \multicolumn{4}{|c|}{$\begin{array}{l}\text { Ensure market } \\
\text { coverage }\end{array}$} & \multicolumn{4}{|c|}{ Optimize space ships } & \multicolumn{4}{|c|}{ Customer loyalty } \\
\hline & OM & $\mathrm{CM}$ & EM & $\mathrm{BM}$ & OM & $\mathrm{CM}$ & EM & $\mathrm{BM}$ & $\mathrm{OM}$ & $\mathrm{CM}$ & EM & BM & $\mathrm{OM}$ & $\mathrm{CM}$ & EM & $\mathrm{BM}$ & OM & $\mathrm{CM}$ & EM & BM \\
\hline GRU & $\mathrm{H}$ & $\mathrm{H}$ & $\mathrm{H}$ & $\mathrm{M}$ & VH & $\mathrm{H}$ & $\mathrm{H}$ & $\mathrm{H}$ & $\mathrm{VH}$ & $\mathrm{M}$ & $\mathrm{H}$ & VH & $\mathrm{H}$ & VH & $\mathrm{H}$ & VH & $\mathrm{H}$ & $\mathrm{M}$ & $\mathrm{M}$ & $\mathrm{H}$ \\
\hline GCS & $\mathrm{H}$ & $\mathrm{H}$ & $\mathrm{VH}$ & $\mathrm{H}$ & $\mathrm{H}$ & $\mathrm{M}$ & $\mathrm{M}$ & $\mathrm{H}$ & $\mathrm{VH}$ & $\mathrm{M}$ & $\mathrm{M}$ & $\mathrm{H}$ & $\mathrm{H}$ & $\mathrm{M}$ & $\mathrm{M}$ & $\mathrm{M}$ & $\mathrm{VH}$ & $\mathrm{VH}$ & $\mathrm{H}$ & $\mathrm{H}$ \\
\hline EB & VH & $\mathrm{H}$ & $\mathrm{VH}$ & $\mathrm{VH}$ & \begin{tabular}{|l|}
$\mathrm{VH}$ \\
\end{tabular} & $\mathrm{H}$ & $\mathrm{H}$ & $\mathrm{VH}$ & $\mathrm{M}$ & $\mathrm{H}$ & $\mathrm{VH}$ & $\mathrm{M}$ & $\mathrm{VH}$ & $\mathrm{H}$ & $\mathrm{H}$ & $\mathrm{H}$ & $\mathrm{H}$ & VH & $\mathrm{H}$ & $\mathrm{H}$ \\
\hline $\mathrm{CP}$ & $\mathrm{H}$ & $\mathrm{H}$ & $\mathrm{VH}$ & $\mathrm{H}$ & $\mathrm{M}$ & $\mathrm{M}$ & $\mathrm{L}$ & $\mathrm{L}$ & $\mathrm{VH}$ & $\mathrm{H}$ & $\mathrm{H}$ & $\mathrm{H}$ & $\mathrm{H}$ & $\mathrm{M}$ & $\mathrm{M}$ & $\mathrm{M}$ & $\mathrm{VH}$ & $\mathrm{H}$ & $\mathrm{M}$ & $\mathrm{H}$ \\
\hline MPI & $\mathrm{VH}$ & $\mathrm{VH}$ & $\mathrm{H}$ & $\mathrm{H}$ & $\mathrm{M}$ & $\mathrm{M}$ & $\mathrm{H}$ & $\mathrm{H}$ & $\mathrm{VH}$ & $\mathrm{H}$ & $\mathrm{H}$ & $\mathrm{H}$ & $\mathrm{L}$ & $\mathrm{M}$ & $\mathrm{M}$ & $\mathrm{L}$ & $\mathrm{VH}$ & $\mathrm{H}$ & $\mathrm{M}$ & $\mathrm{H}$ \\
\hline
\end{tabular}

Fig. 2. "WHAT" - "HOW" correlation scores.

The next phase consists in determining the risks impact in the strategical objectives. The risks were identified previously and they are presented in table 4 . The Fig 3 shows the risks impacts and finally in the Table 5 prioritization of risks is presented.

The results show that the most important risk is low availability of spaces and the company must develop plans to mitigate or eliminate it to improve the supply chain performance. The second risk in priority is low availability of containers and although 
lack of documents or instructions is the low risk once the others have implemented actions also must be addressed.

Table 4. Risks identified to maritime transportation (container shipping).

\begin{tabular}{ll}
\hline Abbreviation & \multicolumn{1}{c}{ Risks } \\
\hline LAS & Low availability of ships \\
DDD & Delay in delivery of the documents \\
FG & Freight contamination \\
LDI & Lack of documents or instructions \\
MI & Mistakes in information \\
CSS & Changes in services and schedules \\
LAS & Low availability of spaces \\
LAC & Low availability of containers \\
\hline
\end{tabular}

\begin{tabular}{|c|c|c|c|c|c|c|c|c|c|c|c|c|c|c|c|c|c|c|c|c|}
\hline & \multicolumn{4}{|c|}{$\begin{array}{c}\text { Improve market share } \\
\text { position }\end{array}$} & \multicolumn{4}{|c|}{$\begin{array}{l}\text { Optimize profit per } \\
\text { shipment }\end{array}$} & \multicolumn{4}{|c|}{$\begin{array}{c}\text { Ensure market } \\
\text { coverage }\end{array}$} & \multicolumn{4}{|c|}{ Optimize space ships } & \multicolumn{4}{|c|}{ Customer loyalty } \\
\hline & $\mathrm{OM}$ & $\mathrm{CM}$ & EM & BM & $\mathrm{OM}$ & $\mathrm{CM}$ & EM & $\mathrm{BM}$ & $\mathrm{OM}$ & $\mathrm{CM}$ & EM & $\mathrm{BM}$ & OM & $\mathrm{CM}$ & EM & $\mathrm{BM}$ & $\overline{\mathrm{OM}}$ & $\mathrm{CM}$ & EM & BM \\
\hline LAS & $\mathrm{H}$ & $\mathrm{H}$ & $\mathrm{VH}$ & $\mathrm{M}$ & $\mathrm{VL}$ & $\mathrm{L}$ & $\mathrm{L}$ & $\overline{\mathrm{VL}}$ & $\mathrm{L}$ & $\mathrm{L}$ & $\mathrm{M}$ & $\overline{V L}$ & $\mathrm{VH}$ & $\mathrm{VH}$ & $\mathrm{H}$ & $\mathrm{VH}$ & $\mathrm{L}$ & $\mathrm{M}$ & $\mathrm{M}$ & $\mathrm{L}$ \\
\hline DDD & $\mathrm{H}$ & $\mathrm{M}$ & $\mathrm{M}$ & $\mathrm{M}$ & $\mathrm{L}$ & $\mathrm{L}$ & $\mathrm{VL}$ & $\mathrm{VL}$ & $\mathrm{M}$ & $\mathrm{M}$ & $\mathrm{H}$ & $\mathrm{M}$ & VH & $\mathrm{H}$ & $\mathrm{VH}$ & VH & $\mathrm{VH}$ & $\mathrm{H}$ & $\mathrm{M}$ & $\mathrm{H}$ \\
\hline \begin{tabular}{|l|} 
FG \\
\end{tabular} & $\mathrm{L}$ & $\mathrm{L}$ & VL & $\mathrm{L}$ & $\mathrm{VL}$ & $\mathrm{L}$ & $\mathrm{L}$ & $\mathrm{L}$ & $\mathrm{L}$ & $\mathrm{L}$ & $\mathrm{L}$ & $\mathrm{L}$ & $\mathrm{H}$ & $\mathrm{H}$ & VH & $\mathrm{M}$ & VH & $\mathrm{M}$ & $\mathrm{H}$ & $\mathrm{H}$ \\
\hline LDI & $\mathrm{M}$ & $\mathrm{H}$ & $\mathrm{L}$ & $\mathrm{M}$ & $\mathrm{L}$ & $\mathrm{L}$ & $\mathrm{L}$ & $\mathrm{VL}$ & $\mathrm{M}$ & $\mathrm{L}$ & $\mathrm{L}$ & $\mathrm{VL}$ & $\mathrm{L}$ & $\mathrm{M}$ & VL & $\mathrm{L}$ & $\mathrm{L}$ & $\mathrm{M}$ & \begin{tabular}{|l}
$\mathrm{VL}$ \\
\end{tabular} & $\mathrm{L}$ \\
\hline MI & $\mathrm{M}$ & $\mathrm{H}$ & $\mathrm{L}$ & $\mathrm{M}$ & $\mathrm{L}$ & $\mathrm{L}$ & $\mathrm{L}$ & $\mathrm{L}$ & $\mathrm{M}$ & $\mathrm{L}$ & $\mathrm{L}$ & $\mathrm{VL}$ & $\mathrm{H}$ & $\mathrm{H}$ & VH & $\mathrm{H}$ & $\mathrm{H}$ & $\mathrm{M}$ & $\mathrm{M}$ & $\mathrm{L}$ \\
\hline CSS & VH & $\mathrm{VH}$ & VH & $\mathrm{H}$ & $\mathrm{VH}$ & $\mathrm{H}$ & $\mathrm{H}$ & $\mathrm{M}$ & VH & $\mathrm{H}$ & $\mathrm{M}$ & $\mathrm{H}$ & $\mathrm{H}$ & $\mathrm{H}$ & $\mathrm{H}$ & $\mathrm{H}$ & $\mathrm{H}$ & VH & $\mathrm{M}$ & $\mathrm{H}$ \\
\hline LAS & VH & $\mathrm{VH}$ & $\mathrm{VH}$ & $\mathrm{VH}$ & $\mathrm{VH}$ & $\mathrm{H}$ & VH & $\mathrm{VH}$ & $\mathrm{VH}$ & $\mathrm{H}$ & $\mathrm{M}$ & $\mathrm{H}$ & $\mathrm{VH}$ & $\mathrm{VH}$ & $\mathrm{VH}$ & $\mathrm{H}$ & $\mathrm{H}$ & $\mathrm{H}$ & VH & $\mathrm{M}$ \\
\hline LAC & VH & $\mathrm{H}$ & VH & $\mathrm{VH}$ & $\mathrm{H}$ & $\mathrm{VH}$ & $\mathrm{VH}$ & $\mathrm{VH}$ & $\mathrm{H}$ & $\mathrm{H}$ & $\mathrm{H}$ & $\mathrm{H}$ & $\mathrm{VH}$ & $\mathrm{M}$ & $\mathrm{H}$ & $\mathrm{H}$ & $\mathrm{H}$ & $\mathrm{H}$ & $\mathrm{M}$ & $\mathrm{VH}$ \\
\hline
\end{tabular}

Fig. 3. Risks impact in strategic objectives.

Table 5. Risks prioritization.

\begin{tabular}{lcccc}
\hline Risk & \multicolumn{3}{c}{$\begin{array}{c}\text { Triangular fuzzy } \\
\text { number }\end{array}$} & $\begin{array}{c}\text { Crisp } \\
\text { number }\end{array}$ \\
\hline Low availability of spaces & 268 & 412 & 602 & $\mathbf{4 2 4}$ \\
Low availability of containers & 253 & 393 & 576 & $\mathbf{4 0 4}$ \\
Changes in services and schedules & 242 & 378 & 557 & $\mathbf{3 8 9}$ \\
Delay in delivery of the & 180 & 294 & 448 & $\mathbf{3 0 4}$ \\
documents & 149 & 252 & 394 & $\mathbf{2 6 2}$ \\
Low availability of ships & 140 & 241 & 379 & $\mathbf{2 5 0}$ \\
Mistakes in information & 128 & 224 & 358 & $\mathbf{2 3 4}$ \\
Freight contamination & 90 & 173 & 290 & $\mathbf{1 8 1}$ \\
Lack of documents or instructions & & & & \\
\hline
\end{tabular}




\section{Conclusions}

We present a novel approach to prioritize risks in supply chain activities involving third party logistics companies (3PL) and particularly in maritime transportation. This approach allows defining the most important risks according with the strategical objectives of the company and thus the company can establish action plans to mitigate or eliminate the risks.

Although in literature there are some papers that using QFD in risk management, there is a lack of papers using FQFD for risk prioritization. Our proposal aims to encourage more works in this field.

We showed that FQFD is a valuable tool in the operational risks assessment so it is important to continue exploring the usefulness of this tool in operational risk management system.

We can prioritize risks according to the strategical objectives of the company and this impact directly in its results and with these results it is possible for the company to define actions in line with its strategy to risk management.

The methodology should be applied throughout the supply chain in order to improve its overall performance.

\section{References}

1. Sener, Z., Ozturk, E.: A QFD-Based Decision Model for Ship Selection in Maritime Transportation. Int J Innov Manag Technol, 6, pp. 202-205, doi: 10.7763/IJIMT.2015.V6.602 (2015)

2. Manotas, D.F., Osorio, J.C., Rivera, L.: Operational Risk Management in Third Party Logistics (3PL). Handb Res Manag Strateg Achiev Optim Perform Ind Process, doi: 10.4018/978-1-5225-0130-5(2016)

3. Dat, L.Q., Phuong, T.T., Kao, H.P., et al.: A new integrated fuzzy QFD approach for market segments evaluation and selection. Appl Math Model, 39, pp. 3653-3665, doi: 10.1016/j.apm.2014.11.051 (2015)

4. Lam, J.S.L., Bai, X.: A quality function deployment approach to improve maritime supply chain resilience. Transp Res Part E Logist Transp Rev., doi: 10.1016/j.tre.2016.01.012 (2015)

5. Lam, J.S.L.: Designing a sustainable maritime supply chain: A hybrid QFD-ANP approach. Transp Res Part E Logist Transp Rev., 78, pp. 70-81, doi: 10.1016/j.tre.2014.10.003 (2015)

6. Razik, M.A., Tahar, R.M., Hasrulnizzam, W., et al.: Integrated Quality Function Deployment (QFD) Model for Dry Bulk Terminal Improvements (DBTI) in Malaysian Ports. J Econ Bus Manag, 3, pp. 4-7, doi: 10.7763/JOEBM.2015.V3.219 (2015)

7. Liang, G.S., Ding, J.F., Wang, C.K.: Applying fuzzy quality function deployment to prioritize solutions of knowledge management for an international port in Taiwan. Knowledge-Based Syst, 33, pp. 83-91, doi: 10.1016/j.knosys.2012.03.012 (2012)

8. Ding, J.F.: Applying fuzzy quality function deployment (QFD) to identify solutions of service delivery system for port of Kaohsiung. Qual Quant, 43, pp. 553-570, doi: 10.1007/s11135-007-9138-7 (2009)

9. Celik, M., Cebi, S., Kahraman, C., Er ID.: An integrated fuzzy QFD model proposal on routing of shipping investment decisions in crude oil tanker market. Expert Syst Appl., 36, pp. 6227-6235, doi: 10.1016/j.eswa.2008.07.031 (2009) 
10. Gento, A.M., Minambres, M.D., Redondo, A., Perez, M.E.: QFD application in a service environment: A new approach in risk management in an university. Oper Res, 1, pp. 115132, doi: 10.1007/BF02936289 (2001)

11. Costantino, F., De Minicis, M., González-Prida, V., Crespo, A.: On the use of quality function deployment (QFD) for the identification of risks associated to warranty programs, 6, pp. 4440-4449 (2012)

12. Bevilacqua, M., Ciarapica, F.E., Giacchetta, G.: A fuzzy-QFD approach to supplier selection. J Purch Supply Manag, 12, pp. 14-27, doi: 10.1016/j.pursup.2006.02.001 (2006)

13. Bottani, E., Rizzi, A.: Strategic management of logistics service: A fuzzy QFD approach. Int J Prod Econ., 103, pp. 585-599, doi: 10.1016/j.ijpe.2005.11.006 (2006)

14. Sohn, S.Y., Choi, I.S.: Fuzzy QFD for supply chain management with reliability consideration. Reliab Eng Syst Saf., 72, pp. 327-334, doi: 10.1016/S0951-8320(01)000229 (2001)

15. Zarei, M., Fakhrzad, M.B., Jamali, M.: Food supply chain leanness using a developed QFD model. J Food Eng., 102, pp. 25-33, doi: 10.1016/j.jfoodeng.2010.07.026 (2011)

16. Hassanzadeh, S., Razmi, J.: An integrated fuzzy model for supplier management: A case study of ISP selection and evaluation. Expert Syst Appl., 36, pp. 8639-8648, doi: 10.1016/j.eswa.2008.10.012 (2009)

17. Kazançoğlu, Y., Aksoy, M.: A fuzzy logic-based quality function deployment for selection of e-learning provider. Turkish Online J Educ Technol., 10, pp. 39-45 (2011)

18. Leina, Z., Tiejun, P., Guoqing, Y.: Process Control and Simulation for the Fourth Party Logistics Using Value Chain Analysis. 2010 Int Conf Electr Control Eng., pp. 1503-1506, doi: 10.1109/iCECE.2010.371 (2010)

19. Wang, F., Li, X.H., Rui, W.N., Zhang, Y.: A fuzzy QFD-based method for customizing positioning of logistics Service products of 3PLS. 2007 Int Conf Wirel Commun Netw Mob Comput WiCOM, pp. 3326-3329, doi: 10.1109/WICOM.2007.825 (2007) 